\title{
Nitrous oxide emission by the non- denitrifying, nitrate ammonifier Bacillus licheniformis
}

\author{
Yihua Sun', Paul De $\operatorname{Vos}^{1,2}$ and Kim Heylen ${ }^{1 *}$
}

\begin{abstract}
Background: Firmicutes have the capacity to remove excess nitrate from the environment via either denitrification, dissimilatory nitrate reduction to ammonium or both. The recent renewed interest in their nitrogen metabolism has revealed many interesting features, the most striking being their wide variety of dissimilatory nitrate reduction pathways. In the present study, nitrous oxide production from Bacillus licheniformis, a ubiquitous Gram-positive, spore-forming species with many industrial applications, is investigated.

Results: $B$. licheniformis has long been considered a denitrifier but physiological experiments on three different strains demonstrated that nitrous oxide is not produced from nitrate in stoichiometric amounts, rather ammonium is the most important end-product, produced during fermentation. Significant strain dependency in end-product ratios, attributed to nitrite and ammonium, and medium dependency in nitrous oxide production were also observed. Genome analyses confirmed the lack of a nitrite reductase to nitric oxide, the key enzyme of denitrification. Based on the gene inventory and building on knowledge from other non-denitrifying nitrous oxide emitters, hypothetical pathways for nitrous oxide production, involving NarG, NirB, qNor and Hmp, are proposed. In addition, all publically available genomes of $B$. licheniformis demonstrated similar gene inventories, with specific duplications of the nar operon, nark and hmp genes as well as NarG phylogeny supporting the evolutionary separation of previously described distinct BALI1 and BALI2 lineages.
\end{abstract}

Conclusions: Using physiological and genomic data we have demonstrated that the common soil bacterium $B$. licheniformis does not denitrify but is capable of fermentative dissimilatory nitrate/nitrite reduction to ammonium (DNRA) with concomitant production of $\mathrm{N}_{2} \mathrm{O}$. Considering its ubiquitous nature and non-fastidious growth in the lab, $B$. licheniformis is a suitable candidate for further exploration of the actual mechanism of $\mathrm{N}_{2} \mathrm{O}$ production in DNRA bacteria and its relevance in situ.

Keywords: Dissimilatory nitrate/nitrite reduction to ammonium (DNRA), Fermentation, Nitrate respiration, Denitrification, Ammonification, Nitrite detoxification

\section{Background}

Denitrification and dissimilatory nitrate/nitrite reduction to ammonium (DNRA) are two key processes, performed by a wide range of Bacteria and Archaea as well as some Eukaryotes [1], responsible for removal of excess nitrate from the environment. Denitrification is the modular step-wise reduction of fixed nitrogen, nitrate or nitrite to a gaseous form, either nitric oxide (NO),

\footnotetext{
*Correspondence: Kim.Heylen@ugent.be

'Department of Biochemistry and Microbiology, Laboratory of Microbiology, (LM-UGent), University of Ghent, K.L. Ledeganckstraat 35, 9000 Gent, Belgium Full list of author information is available at the end of the article
}

nitrous oxide $\left(\mathrm{N}_{2} \mathrm{O}\right)$ and/or dinitrogen gas $\left(\mathrm{N}_{2}\right)$. DNRA retains nitrogen in the environment, although $\mathrm{N}_{2} \mathrm{O}$, contributor to both climate change and ozone depletion in the stratosphere, can also be produced as side product. Comprehensive understanding of the identities and activities of microorganisms as well as cellular mechanisms involved in nitrate removal are crucial for improving models that predict fluxes of nitrate, nitrite and $\mathrm{N}_{2} \mathrm{O}$ [2]. Although several Firmicutes have been known for a long time to be nitrate reducers and $\mathrm{N}_{2} \mathrm{O}$ emitters [3-8], their ecological relevance has been minimalized over the past two decades based on molecular community surveys 
using primers not targeting their divergent denitrification [9-12] or DNRA genes [13] (note that recent primers for DNRA do indeed target Firmicute genes [14]). Nevertheless, Firmicutes and specifically Bacillus can be dominant in ecosystems with important nitrate removal activities such as soil [15], animal manure compost [16] and advanced wastewater treatments [17].

Renewed interest in Bacillus has revealed many interesting features like (i) the widespread occurrence of nitrate reduction and denitrification in the genus [18], (ii) the gene inventory for both denitrification and DNRA in one microorganism [19, 20], (iii) a novel type of copper-Adependent, electrogenic nitric oxide reductase $\left(\mathrm{Cu}_{\mathrm{A}} \mathrm{Nor}\right)$ [21-24], or (iv) membrane-bound denitrification [25] with a novel organization for the periplasmic nitrate reductase $[19,26]$. The most striking observation however is the wide variety of dissimilatory nitrate reduction pathways in members of this genus. The model organism Bacillus subtilis uses the cytoplasmic nitrate reductase NarGHI and nitrite reductase NirBD to anaerobically reduce nitrate to ammonium [27, 28], while Bacillus selenitireducens produces ammonium via the periplasmic nitrite reductase NrfA [14, 29]. Bacillus vireti can do the same but with concomitant $\mathrm{N}_{2} \mathrm{O}$ production via $\mathrm{Cu}_{\mathrm{A}}$ Nor that can be converted to the harmless $\mathrm{N}_{2}$ with a NosZ-type reductase [30]. On the other hand, Bacillus azotoformans and Bacillus bataviensis are canonical denitrifiers, the latter lacking the final reductase, but both also encode the NrfA nitrite reductase, making them potential ammonium producers [19]. In addition, these two organisms demonstrate an unusual high level of gene redundancy, i.e. multiple genes or gene copies encoding the same function (B. azotoformans encodes three nitrate, two nitrite, four $\mathrm{NO}$ and three $\mathrm{N}_{2} \mathrm{O}$ reductases) [19]. Considering the modularity of denitrification and DNRA, a multitude of enzyme combinations for nitrate reduction are imaginable, even within one microorganism.

Bacillus licheniformis, a close relative of B. subtilis, is widely distributed as a saprophytic organism in the environment, has numerous commercial and agricultural uses (e.g. production of peptide antibiotics, chemicals and proteases, mitigation of fungal pathogens) and some strains, with abortifacient potential or toxin production, might pose a threat to public health. Certain B. licheniformis isolates have been described as denitrifiers $[5,18,28]$, mostly based on their ability to produce gas from nitrate anaerobically. Many genomes from $B$. licheniformis have been sequenced and described to date [31-36]. However, their lack of genes encoding either a copper- or cytochrome $c d_{1}$-dependent nitrite reductase (NirK or NirS respectively), the key enzyme of denitrification, has gone unnoticed, probably because of limited interest in their anaerobic nitrogen metabolism. We have sequenced and analyzed the genomes of three $B$. licheniformis strains previously reported to produce $\mathrm{N}_{2} \mathrm{O}$ [18], and confirmed the lack of nirS or nirK in their genomes. In addition, physiological data was gathered demonstrating that $B$. licheniformis does not denitrify but is capable of fermentative dissimilatory nitrate/nitrite reduction to ammonium with concomitant production of $\mathrm{N}_{2} \mathrm{O}$. Both types of data were combined to propose hypothetical pathways for $\mathrm{N}_{2} \mathrm{O}$ production, which present new alternative routes for nitrate reduction and $\mathrm{N}_{2} \mathrm{O}$ production in members of the genus Bacillus.

\section{Methods}

\section{Strains and DNA extraction}

B. licheniformis LMG 6934, LMG 7559 and LMG 17339 were obtained from the BCCM/LMG bacteria collection. Strains were grown aerobically in trypticase soy broth (TSB) at $37{ }^{\circ} \mathrm{C}$. Cells were harvested after overnight growth and DNA was extracted by the method of Pitcher et al. [37], slightly modified as described previously [38].

\section{Genome sequencing \& annotation}

Library preparation and genome sequencing was performed by Baseclear B.V. For sequencing, paired-end strategy on the Illumina Genome Analyzer IIx was used yielding average read lengths of 75 bp for LMG 7759 and LMG 17339 and $50 \mathrm{bp}$ for LMG 6934. Automatic trimming (based on a threshold of $\mathrm{Q}=20$ and maximum 2 ambiguous bases) and assembly was performed using CLC Genomics Workbench 6.5. The k-mer and bubble size parameters were varied to maximize the N50 and the number of contig of the resulting assembly for each genome. For the consensus sequence, conflicts were resolved by using quality scores and insertion of ambiguity codes. Functional annotation and metabolic reconstruction was performed with the Rapid Annotation Subsystem Technology (RAST) server [39, 40], using RAST gene calling and allowing frame shift correction, backfilling of gaps and automatic fixing of errors. Assigned functions were checked with pBLAST [41] and InterProScan [42]. Missing genes were searched for in the genome with PSI-BLAST using homologous amino acid sequences. The average nucleotide identity (ANI) was calculated with the ANI calculator (http://enve-omics.ce.gatech.edu/ani/) [43].

\section{Growth experiments}

Anaerobic growth experiments were performed in TSB and mineral medium (MM), amended with $10 \mathrm{mM}$ potassium nitrate as electron acceptor. Mineral medium was as described by Stanier et al. [44], including $10 \mathrm{mM}$ phosphate buffer, $2.3 \mathrm{mM}\left(\mathrm{NH}_{4}\right)_{2} \mathrm{SO}_{4}, 0.4 \mathrm{mM} \mathrm{MgSO}_{4} \cdot 7 \mathrm{H}_{2} \mathrm{O}$, $0.04 \mathrm{mM} \mathrm{CaCl}_{2} \cdot 2 \mathrm{H}_{2} \mathrm{O}, 2.3 \mathrm{mM}\left(\mathrm{NH}_{4}\right)_{2} \mathrm{SO}_{4}, 27 \mu \mathrm{M}$ EDTA, $25 \mu \mathrm{M} \quad \mathrm{FeSO}_{4} \cdot 7 \mathrm{H}_{2} \mathrm{O}, 10 \mu \mathrm{M} \quad \mathrm{ZnSO}_{4} \cdot 7 \mathrm{H}_{2} \mathrm{O}, 25 \mu \mathrm{M}$ 
$\mathrm{MnSO}_{4} \cdot \mathrm{H}_{2} \mathrm{O}, \quad 3.8 \mu \mathrm{M} \quad \mathrm{CuSO}_{4} \cdot 5 \mathrm{H}_{2} \mathrm{O}, 2 \mu \mathrm{M} \quad \mathrm{Co}(\mathrm{N}-$ $\left.\mathrm{O}_{3}\right) 2 \cdot 6 \mathrm{H}_{2} \mathrm{O}, 0.196 \mu \mathrm{M}\left(\mathrm{NH}_{4}\right)_{6} \mathrm{Mo}_{7} \mathrm{O}_{24} \cdot 24 \mathrm{H}_{2} \mathrm{O}$, supplemented with $30 \mathrm{mM}$ glucose as electron donor. Serum vials $(120 \mathrm{ml})$ were rinsed with $1 \mathrm{M} \mathrm{HCl}$ overnight to remove growth inhibiting substances, and subsequently washed four times and rinsed with distilled water before use. Serum vials with $50 \mathrm{ml}$ medium were sealed with black butyl-rubber stoppers. After autoclaving, the headspace of the serum vials was replaced via five cycles of evacuating and refilling with helium. Serum vials were inoculated $(1 \% \mathrm{v} / \mathrm{v})$ with a suspension of optical density $\mathrm{OD}_{600}$ of $1.0 \pm 0.05$. Each growth experiment was performed in triplicate and non-inoculated media in duplicate were included to check for potential nitrosation reactions in sterile medium. After inoculation, serum vials were incubated at $37^{\circ} \mathrm{C}, 150 \mathrm{rpm}$, for $72 \mathrm{~h}$. Preliminary end-point analyses demonstrated that all three strains did not produce $\mathrm{N}_{2}$ (later confirmed by absence of nos $Z$ gene from the genomes, see further) so their dissimilatory nitrate reduction metabolism was explored without addition of acetylene to the headspace. Statistical differences in growth rate and yield of LMG 6934 between TSB and TSB amended with $10 \mathrm{mM}$ nitrate were assessed using the independent t-test after Levene's test for equality of variances, and main and interaction effect of medium and strain on end-product concentration using factorial ANOVA and Least Significant Difference post-hoc testing in SPSS23.

\section{Analytical procedures}

Samples of $1 \mathrm{ml}$ were taken from cultures through the rubber septum of serum vials with sterile syringes for growth determination and colorimetric determination of ammonium, nitrate and nitrite. Growth was determined by measuring the optical density $\mathrm{OD}_{600}$ of $100 \mu \mathrm{l}$ sample in duplicate in microtiter plates and standardized to $1 \mathrm{~cm}$ pathlength using PathCheck Sensor of the spectrophotometer (Molecular Devices, Spectramax plus 384, USA). For colorimetrics, $500 \mu \mathrm{l}$ from remaining sample was pretreated with $2.5 \mathrm{ml}$ of $2 \mathrm{M}$ potassium chloride by shaking $1 \mathrm{~h}$ at $150 \mathrm{rpm}$ and subsequent filtration $(0.2 \mu \mathrm{m})$ to extract inorganic nitrogen and remove interfering compounds. Filtered samples were centrifuged at $13000 \mathrm{rpm}$ for 2 min to remove the cells and kept frozen at $-20{ }^{\circ} \mathrm{C}$ until colorimetric determination. Ammonium concentration was determined with the salicylate-nitroprussidine method (absorption at a wavelength of $650 \mathrm{~nm}$ ) [45], nitrite and nitrate concentrations were determined with Griess reaction [46] and Griess reaction with cadmium $[47,48]$ respectively. For end-point measurements, ammonium production was corrected per strain for the amount of ammonium assimilated based on $\mathrm{OD}_{600}$ values obtained. Standard curves covered ranges suitable for the tested media and were strictly linear with an $R_{2}$ of 0.99 .
For determination of $\mathrm{N}_{2} \mathrm{O}, 1 \mathrm{ml}$ sample of the headspace of serum vials was taken with sterile syringes, and was injected into the gas chromatograph (Compact GC with EZChrom Elite Software, Interscience, Netherlands, 2012). $\mathrm{N}_{2} \mathrm{O}$ concentrations were corrected for pressure and solubility based on Henry's law.

\section{Accession numbers}

The Whole Genome Shotgun projects of B. licheniformis LMG 6934, LMG 7559 and LMG 17339 have been deposited at DDBJ/EMBL/GenBank under the accession numbers AZSY00000000, AZSX00000000, and AZSZ00000000 respectively. The versions described in this paper are the first versions.

\section{Results}

Dissimilatory nitrate reduction metabolism

Three genotypically distinct $B$. licheniformis strains (Coorevits, A. \& De Vos, P., personal communication) from various origins were selected for determination of their dissimilatory nitrate reduction metabolism based on a previous study that demonstrated their capacity to produce $\mathrm{N}_{2} \mathrm{O}$ [18]. B. licheniformis LMG 6934 was originally isolated from garden soil, LMG 7559 from flour and LMG 17339 from silage.

Growth of LMG 6934 (Fig. 1a) under anaerobic headspace in TSB amended without and with nitrate $(11 \mathrm{mM})$ commenced after a short lag phase of approximately $3 \mathrm{~h}$, a steep exponential phase followed, with maximal growth achieved after $8.5 \mathrm{~h}$, after which cells sporulated very quickly without a stationary phase (Fig. 1a). Between 6.5 and $7.5 \mathrm{~h}$, growth slowed down probably due to a depletion of the preferential carbon source in the medium with a shift to another electron donor, as this was observed both for fermentative and respiratory growth. The anaerobic growth rates were comparable with and without nitrate as electron acceptor $\left(\mu_{\text {nitrate }} / \mathrm{h}=0.189 \pm 0.004 \mathrm{~h}^{-1}\right.$ and $\mu_{\text {ferm }}=$ $\left.0.179 \pm 0.011 \mathrm{~h}^{-1}(p=0.264)\right)$, but with significantly different maximal growth yield $\left(\mathrm{OD}_{600}\right.$ of $1.05 \pm 0.02$ with nitrate and $0.75 \pm 0.06$ without nitrate $(p=0.002))$ reflecting the different ATP yield of a respiratory and a fermentative life style. In the presence of nitrate (Fig. $1 \mathrm{~b}$ ), growth was initially supported by nitrate reduction $\left(\mu_{1}=0.19 \pm 0.004 \mathrm{~h}^{-1}\right)$, with concomitant nitrite production. All nitrate was converted to nitrite but the maximal nitrite peak was probably missed between 5 and $6.5 \mathrm{~h}$ of incubation, which was deduced from the onset of $\mathrm{N}_{2} \mathrm{O}$ production $\left(0.2 \mathrm{mM} \mathrm{N}-\mathrm{N}_{2} \mathrm{O}\right.$ at $6.5 \mathrm{~h}$ ). When nitrate was almost depleted (at $6.5 \mathrm{~h}$, $0.62 \mathrm{mM}$ residual nitrate), nitrite was reduced ( $\mu_{2}=0.16 \pm$ $0.02 \mathrm{~h}^{-1}$ ), which continued after maximal growth at $8.5 \mathrm{~h}$ was achieved and sporulation had started $\left(\mu_{3}\right)$. This suggested that nitrite reduction did not support growth during the $\mu_{2}$ phase, but rather fermentation was responsible for growth after nitrate depletion. During nitrite reduction, a 


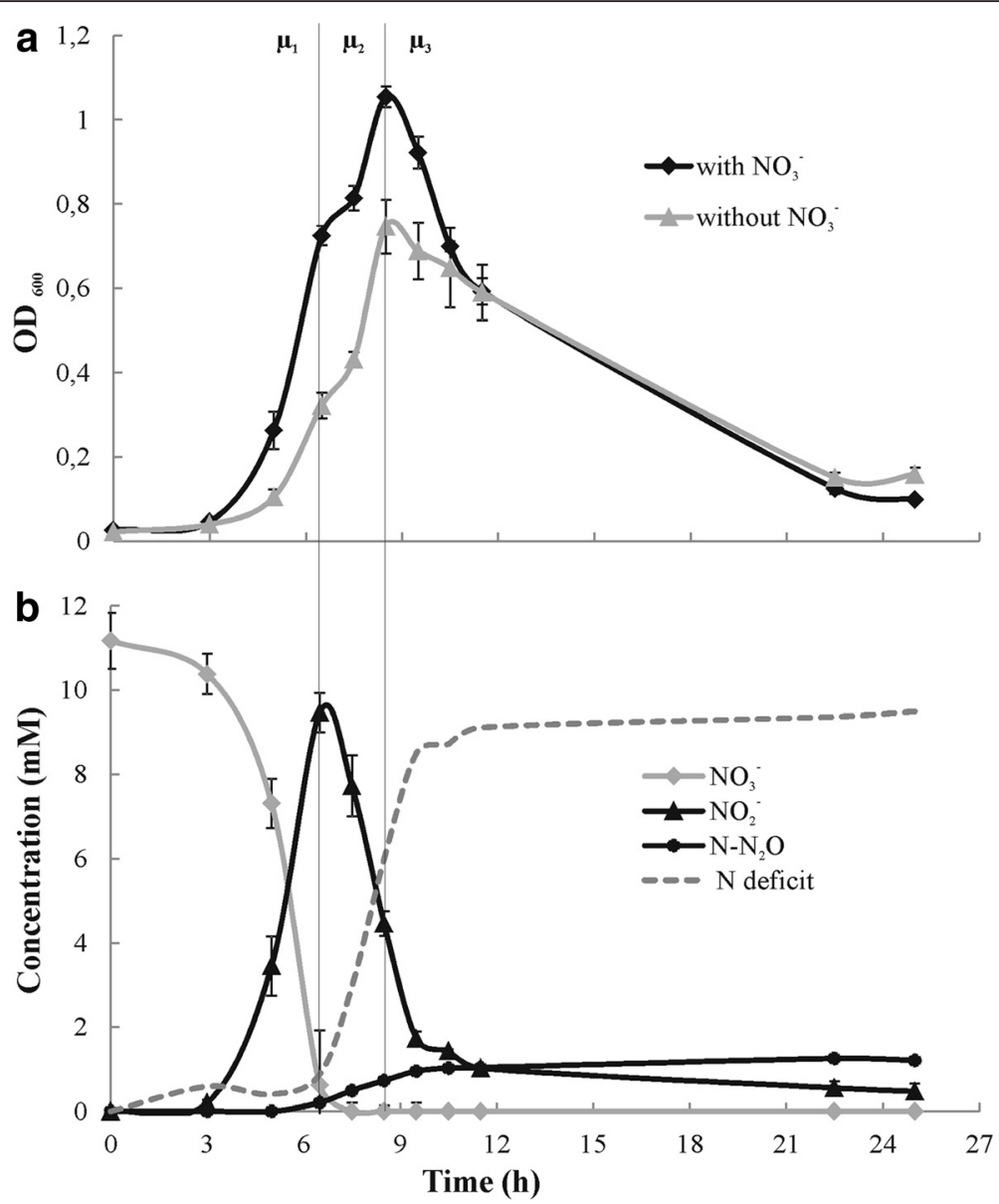

Fig. 1 Anaerobic growth $\left(\mathrm{OD}_{600}\right)$ of B. licheniformis LMG 6934 in TSB (a) and nitrate, nitrite and $\mathrm{N}_{2} \mathrm{O}$ concentrations (mM)(b) over time. Error bars show standard deviation $(n=3)$. Different growth phases based on primary metabolism in TSB amended with nitrate are marked: $\mu_{1}$, respiratory growth with nitrate as electron acceptor; $\mu_{2}$, fermentative growth after nitrate is depleted; $\mu_{3}$, sporulation. Dashed curve visualizes $N$ deficit caused by the lack of ammonium data

continuous increase in $\mathrm{N}_{2} \mathrm{O}$ was observed, with a maximum of $1.3 \pm 0.07 \mathrm{mM} \mathrm{N}-\mathrm{N}_{2} \mathrm{O}$ at the end of the incubation (accounting for $12 \%$ of all reduced nitrite), and $0.5 \pm$ $0.18 \mathrm{mM}$ of nitrite remaining in the medium (Fig. 1b). Due to technical constraints and interference of amines from degradation of proteins in the TSB during bacterial growth, ammonium was not monitored during these growth experiments.

To compare the dissimilatory nitrate reduction metabolism of LMG 6934 with those of LMG 7559 and LMG 17339 and to confirm ammonium production from nitrite, end-point experiments after a $72 \mathrm{~h}$-incubation in anaerobic conditions were performed in TSB and mineral medium with $30 \mathrm{mM}$ glucose, both amended with nitrate. Maximal growth of LMG 7559 and LMG 17339 was achieved within $11 \mathrm{~h}$, again immediately followed by a rapid sporulation (data not shown). In mineral media with glucose, most nitrate was converted to ammonium (31.8 to $89.1 \%$; Fig. 2), confirming the ammonium-producing capacity of all three strains (for TSB, the nitrogen deficit was attributed to ammonium production, which could not be measured). A significant strain effect on the ratios of end-products was observed $(p \leq 0.008)$ (Fig. 2), which after decomposition appeared to be mostly attributed to differences in ammonium and nitrite concentrations. In addition, the amount of $\mathrm{N}-\mathrm{N}_{2} \mathrm{O}$ produced from nitrate was substantially lower in mineral medium than in TSB for all strains $(15.8-32.9 \%$ for TSB vs $10.9-24.1 \%$ in MM) $(p=0.023)$. Only for LMG 17339 , the medium also had a significant effect on ammonium and nitrite $(p \leq 0.024)$. Both strain and medium effect were quite unexpected, as the three strains are closely related and the major carbon source in TSB, namely glucose, is also used in the mineral medium.

\section{Genome analyses}

Draft genomes of the three $B$. licheniformis strains were obtained, the genome statistics are given in Table 1. The gene inventory for assimilatory and dissimilatory nitrate reduction and related transport and regulation was 


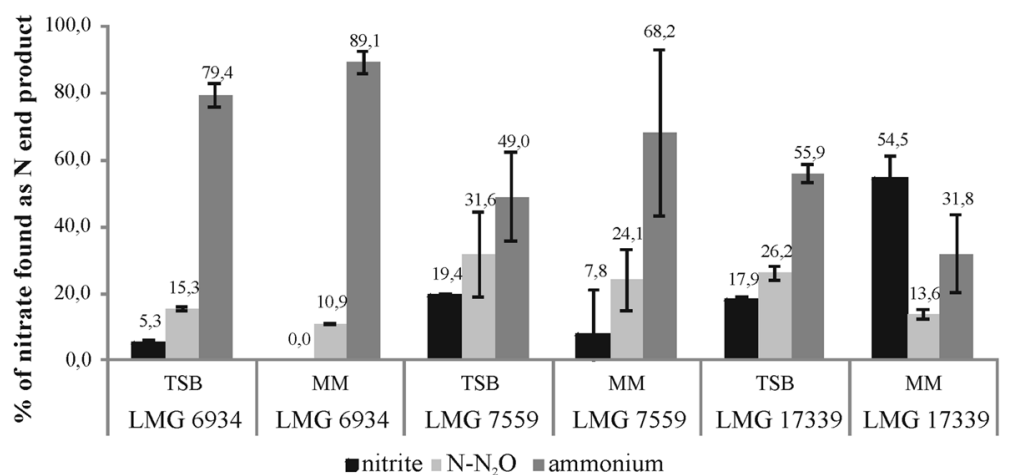

Fig. 2 Percentages of end-products of anaerobic nitrate reduction by B. licheniformis strains in TSB and mineral medium with 30 mM glucose (MM), amended with $10 \mathrm{mM}$ nitrate. Error bars represent standard deviation $(n=3)$. The larger error bars for LMG 7559 result from differences in one of the three replicates. Measured concentrations of ammonium were corrected for loss through assimilation. N deficit in TSB experiments was attributed to ammonium production, which could not be measured, and visualized as such for convenience of comparison

almost identical for the three genomes (Table 2). Details will be given for LMG 6934 and differences with LMG 7559 and LMG 17339 will be highlighted.

The genome of LMG 6934 contained two copies of the nar operon (narGHJI) coding for the cytoplasmic, membrane-bound nitrate reductase (Table 2; Additional file 1: Figure S1). The two NarG sequences are quite divergent, only sharing $53.7 \%$ amino acid sequence identity. The narl operon (Fig. 3) is located in a gene cluster with downstream the genes for the anaerobic regulatory protein Fnr (Fumarate-Nitrate reductase Regulation) (fnr1), a NarK2-type low-affinity nitrate/nitrite antiporter (narK1) (Additional file 1: Figure S2), a second Fnr (fnr2), a quinoldependent NO reductase (qnorB) and a NO-dependent regulator $(d n r N)$. The nar2 operon (Fig. 3) is immediately downstream of CDS for a second NarK2-type nitrate/nitrite antiporter (narK2) (Additional file 1: Figure S2) and a flavohemoprotein ( $h m p 1)$. The two-component nitrate/nitrite sensor regulator system (narXL) is encoded downstream of the genes for a nitrite-sensitive transcriptional repressor of NO stress response (nsrR) and a second flavohemoprotein (hmp2), while genes for a third NarK2-type

Table 1 Genome characteristics of three analyzed $B$. licheniformis genomes. Number of coding sequences is based on annotation obtained via RAST

\begin{tabular}{llll}
\hline & LMG 6934 & LMG 7559 & LMG 17339 \\
\hline \# contigs (\# bp) & 53 & 69 & 80 \\
& $(4,138,686$ bp) & $(4,341,862$ bp) & $(4,333,151$ bp) \\
N $_{50}$ & 654,545 & 123,311 & 102,733 \\
av. read coverage & 87.4 & 82.3 & 233.7 \\
$\%$ G + C & 45.9 & 45.8 & 46.1 \\
RNA & 1 rRNA & 1 rRNA & 1 rRNA \\
& operon30 tRNA & operon30 tRNA & operon36 tRNA \\
\# coding sequences & 4576 & 4559 & 4425 \\
accession number & AZSY00000000 & AZSX00000000 & AZSZ00000000 \\
\hline
\end{tabular}

nitrate/nitrite antiporter (narK3), a formate/nitrite transporter (nirC), a second narL copy NO reductase activation proteins $(n o r D Q)$, and the global nitrogen regulator $(\operatorname{tn} r A)$ are found separate on the genome. The gene for NO synthase (nos) was also found. Two genes encoding a putative NorV, a flavorubredoxin that could be capable of detoxification of $\mathrm{NO}$ to $\mathrm{N}_{2} \mathrm{O}[49,50]$, were also found. However, no gene for the associated oxidoreductase NorW or regulator NorR were found down- and upstream respectively, suggesting that NorV is unlikely to be functional as NO reductase. Nevertheless, all features for nitrate sensing, transport, reduction to nitrite and its regulation are found, as well as for $\mathrm{NO}$ reduction to $\mathrm{N}_{2} \mathrm{O}$. In addition, related to nitrogen assimilation, the operon for assimilatory nitrate and nitrite reduction and two genes for AmtB-type ammonium transporters with each upstream the regulatory gene $g \ln K$ are found. Notably, genes for a NirS- or NirK-type nitrite reductase to NO, a NosZ-type $\mathrm{N}_{2} \mathrm{O}$ reductase, or a Nrftype nitrite reductase to ammonium are absent from the genome. The gene inventory and organization for LMG 7559 was identical to LMG 6934 (Table 2). Note that strain LMG 7559 is equivalent to ATTC 9945, for which a complete genome sequence has already been published since the start of our genome analyses [33]. For clarity, both genomes will be included in the remainder of the genome analyses. The genome of LMG 17339 only contained one nar operon, two NarK2-type nitrate/nitrite antiporters and one copy of hmp and narL (associated with $n a r X)$, but for the remainder was identical in gene content and organization to LMG 6934 (Table 2).

Whole genome clustering based on the peptidome content $[51,52]$, in which the amino acid sequences of a genome are converted to tryptic peptides, i.e. the tryptic peptidome, of all publically available $B$. licheniformis genomes (dd June 2014) confirmed the two generally accepted distinct lineages within B. licheniformis, BALI1 and BALI2 [53] (Additional file 1: Figure S3). Average 
Table 2 Overview of gene inventory involved in nitrogen metabolism, transport and regulation of Bacillus licheniformis

\begin{tabular}{|c|c|c|c|c|c|}
\hline \multirow[t]{2}{*}{ function } & \multirow[t]{2}{*}{ protein } & \multirow[t]{2}{*}{ gene } & \multicolumn{3}{|l|}{ locus_tag (gene coordinates) } \\
\hline & & & LMG 6934 & LMG 7559 & LMG 17339 \\
\hline \multirow[t]{8}{*}{$\begin{array}{l}\text { dissimilatory nitrate } \\
\text { reduction to nitrite }\end{array}$} & \multirow[t]{2}{*}{$\begin{array}{l}\text { respiratory nitrate reductase } \\
\text { subunit alpha }\end{array}$} & narG1 & $\begin{array}{l}\text { L16934_10240 } \\
\text { (contig17_44191_40505) }\end{array}$ & $\begin{array}{l}\text { L17559_10220 } \\
\text { (contig17_109260_112943) }\end{array}$ & $\begin{array}{l}\text { LI17339_03250 } \\
\text { (contig01_602796_599110) }\end{array}$ \\
\hline & & narG2 & $\begin{array}{l}\text { L16934_11815 } \\
\text { (contig19_3766_7449) }\end{array}$ & $\begin{array}{l}\text { Ll7559_18375 } \\
\text { (contig29_333921_330235) }\end{array}$ & - \\
\hline & \multirow[t]{2}{*}{$\begin{array}{l}\text { respiratory nitrate reductase } \\
\text { subunit beta }\end{array}$} & narH1 & $\begin{array}{l}\text { Ll6934_10235 } \\
\text { (contig17_40515_39046) }\end{array}$ & $\begin{array}{l}\text { Ll7559_10225 } \\
\text { (contig17_112933_114483) }\end{array}$ & $\begin{array}{l}\text { LI17339_03245 } \\
\text { (contig01_599120_597651) }\end{array}$ \\
\hline & & narH2 & $\begin{array}{l}\text { Ll6934_11820 } \\
\text { (contig19_7439_8989) }\end{array}$ & $\begin{array}{l}\text { LI7559_18370 } \\
\text { (contig29_330245_328776) }\end{array}$ & - \\
\hline & \multirow[t]{2}{*}{$\begin{array}{l}\text { respiratory nitrate reductase } \\
\text { subunit delta }\end{array}$} & narJ1 & $\begin{array}{l}\text { L16934_10230 } \\
\text { (contig17_39028_38486) }\end{array}$ & $\begin{array}{l}\text { Ll7559_10230 } \\
\text { (contig17_114470_115018) }\end{array}$ & $\begin{array}{l}\text { Ll17339_03240 } \\
\text { (contig01_597632_597090) }\end{array}$ \\
\hline & & narJ2 & $\begin{array}{l}\text { L16934_11825 } \\
\text { (contig19_8976_9524) }\end{array}$ & $\begin{array}{l}\text { Ll7559_18365 } \\
\text { (contig29_328758_328216) }\end{array}$ & - \\
\hline & \multirow[t]{2}{*}{$\begin{array}{l}\text { respiratory nitrate reductase } \\
\text { subunit gamma }\end{array}$} & narl1 & $\begin{array}{l}\text { L16934_10225 } \\
\text { (contig17_38489_37803) }\end{array}$ & $\begin{array}{l}\text { Ll7559_10235 } \\
\text { (contig17_115039_115740) }\end{array}$ & $\begin{array}{l}\text { LI17339_03235 } \\
\text { (contig01_597093_596407) }\end{array}$ \\
\hline & & narl2 & $\begin{array}{l}\text { Ll6934_11830 } \\
\text { (contig19_9545_10246) }\end{array}$ & $\begin{array}{l}\text { LI7559_18360 } \\
\text { (contig29_328219_327533) }\end{array}$ & - \\
\hline $\begin{array}{l}\text { assimilatory } \\
\text { nitrate/nitrite }\end{array}$ & $\begin{array}{l}\text { assimilatory nitrate reductase } \\
\text { large subunit }\end{array}$ & nasC & $\begin{array}{l}\text { Ll6934_20135 } \\
\text { (contig48_34712_36769) }\end{array}$ & $\begin{array}{l}\text { LI7559_01055 } \\
\text { (contig02_88956_91013) }\end{array}$ & $\begin{array}{l}\text { LI17339_17560 } \\
\text { (contig10_88671_90728) }\end{array}$ \\
\hline \multirow[t]{2}{*}{$\begin{array}{l}\text { reduction to } \\
\text { ammonium }\end{array}$} & $\begin{array}{l}\text { assimilatory nitrite reductase } \\
{[N A D(P) H] \text { large subunit }}\end{array}$ & $\operatorname{nirB}$ & $\begin{array}{l}\text { Ll6934_20140 } \\
\text { (contig48_36883_39303) }\end{array}$ & $\begin{array}{l}\text { LI7559_01060 } \\
\text { (contig02_91127_93547) }\end{array}$ & $\begin{array}{l}\text { Ll17339_17565 } \\
\text { (contig10_90842_93262) }\end{array}$ \\
\hline & $\begin{array}{l}\text { assimilatory nitrite reductase } \\
{[N A D(P) H] \text { small subunit }}\end{array}$ & $\operatorname{nirD}$ & $\begin{array}{l}\text { Ll6934_20145 } \\
\text { (contig48_39334_39654) }\end{array}$ & $\begin{array}{l}\text { L17559_01065 } \\
\text { (contig02_93578_93898) }\end{array}$ & $\begin{array}{l}\text { Ll17339_17560 } \\
\text { (contig10_93293_93613) }\end{array}$ \\
\hline \multirow[t]{6}{*}{ transporters } & \multirow[t]{2}{*}{ ammonium transport } & amt1 & $\begin{array}{l}\text { Ll6934_11075 } \\
\text { (contig18_87147_88526) }\end{array}$ & $\begin{array}{l}\text { LI7559_21025 } \\
\text { (contig40_60895_59966) }\end{array}$ & $\begin{array}{l}\text { LI17339_05915 } \\
\text { (contig03_429269_428058) }\end{array}$ \\
\hline & & amt2 & $\begin{array}{l}\text { Ll6934_06945 } \\
\text { (contig13_69958_71169) }\end{array}$ & $\begin{array}{l}\text { LI7559_12245 } \\
\text { (contig20_86027_87406) }\end{array}$ & $\begin{array}{l}\text { Ll17339_15165 } \\
\text { (contig06_266544_265900) }\end{array}$ \\
\hline & \multirow[t]{3}{*}{$\begin{array}{l}\text { nitrate/nitrite transporter } \\
\text { (Nark2-type) }\end{array}$} & nark1 & $\begin{array}{l}\text { Ll6934_10275 } \\
\text { (contig17_50582_49398) }\end{array}$ & $\begin{array}{l}\text { Ll7559_10215 } \\
\text { (contig17_107711_109207) }\end{array}$ & $\begin{array}{l}\text { LI17339_03285 } \\
\text { (contig01_609186_608002) }\end{array}$ \\
\hline & & nark2 & $\begin{array}{l}\text { L16934_11810 } \\
\text { (contig19_2217_3713) }\end{array}$ & $\begin{array}{l}\text { L17559_18410 } \\
\text { (contig29_340309_339125) }\end{array}$ & $\begin{array}{l}\text { LI17339_16960 } \\
\text { (contig09_16054_161849) }\end{array}$ \\
\hline & & nark3 & $\begin{array}{l}\text { Ll6934_04585 } \\
\text { (contig09_42906_44111) }\end{array}$ & $\begin{array}{l}\text { LI7559_1255 } \\
\text { (contig21_43506_44711) }\end{array}$ & - \\
\hline & formate/nitrite transporter & nirC & $\begin{array}{l}\text { Ll6934_08170 } \\
\text { (contig13_306187_306975) }\end{array}$ & $\begin{array}{l}\text { LI7559_03215 } \\
\text { (contig06_176423_177211) }\end{array}$ & $\begin{array}{l}\text { LI17339_04610 } \\
\text { (contig03_178114_177326) }\end{array}$ \\
\hline \multirow[t]{3}{*}{$\begin{array}{l}\mathrm{NO} \text { reduction } \\
\text { to } \mathrm{N}_{2} \mathrm{O}\end{array}$} & $\begin{array}{l}\text { NO reductase large } \\
\text { subunit-like protein }\end{array}$ & qnorB & $\begin{array}{l}\text { L16934_10290 } \\
\text { (contig17_51910_54264) }\end{array}$ & $\begin{array}{l}\text { Ll7559_18425 } \\
\text { (contig29_341636_343990) }\end{array}$ & $\begin{array}{l}\text { LI17339_03300 } \\
\text { (contig01_610516_612870) }\end{array}$ \\
\hline & \multirow[t]{2}{*}{ NO reductase activation protein } & norD1 & $\begin{array}{l}\text { LI6934_02700 } \\
\text { (contig04_119995_118082) }\end{array}$ & $\begin{array}{l}\text { LI7559_00105 } \\
\text { (contig01_24308_22395) }\end{array}$ & $\begin{array}{l}\text { LI17339_13375 } \\
\text { (contig04_735870_736760) }\end{array}$ \\
\hline & & norD2 & $\begin{array}{l}\text { Ll6934_02705 } \\
\text { (contig04_120896_120006) }\end{array}$ & $\begin{array}{l}\text { LI7559_00110 } \\
\text { (contig01_25209_24319) }\end{array}$ & $\begin{array}{l}\text { Ll17339_13380 } \\
\text { (contig04_736770_738683) }\end{array}$ \\
\hline \multirow[t]{3}{*}{ detoxification } & \multirow[t]{2}{*}{ flavohemoglobin } & hmpl & $\begin{array}{l}\text { pLI6934_11805 } \\
\text { (contig19_1907_689) }\end{array}$ & $\begin{array}{l}\text { LI7559_10210 } \\
\text { (contig17_107401_106181) }\end{array}$ & $\begin{array}{l}\text { LI17339_14225 } \\
\text { (contig06_89281_88067) }\end{array}$ \\
\hline & & hmp2 & $\begin{array}{l}\text { Ll6934_03825 } \\
\text { (contig07_12629_11415) }\end{array}$ & $\begin{array}{l}\text { LI7559_14100 } \\
\text { (contig23_84124_85338) }\end{array}$ & - \\
\hline & NO synthase & nos & $\begin{array}{l}\text { Ll6934_16440 } \\
\text { (contig34_14900_15997) }\end{array}$ & $\begin{array}{l}\text { LI7559_14725 } \\
\text { (contig27_17226_16129) }\end{array}$ & $\begin{array}{l}\text { LI17339_20905 } \\
\text { (contig20_78781_79878) }\end{array}$ \\
\hline \multirow[t]{3}{*}{ regulation } & \multirow[t]{2}{*}{$\begin{array}{l}\mathrm{P}_{\|} \text {-type signal } \\
\text { transduction protein }\end{array}$} & $g \ln K 1$ & $\begin{array}{l}\text { Ll6934_11070 } \\
\text { (contig18_86749_87090) }\end{array}$ & $\begin{array}{l}\text { LI7559_12240 } \\
\text { (contig20_85629_85970) }\end{array}$ & $\begin{array}{l}\text { Ll17339_05910 } \\
\text { (contig03_428039_427689) }\end{array}$ \\
\hline & & $g \ln K 2$ & $\begin{array}{l}\text { Ll6934_06950 } \\
\text { (contig13_71188_71538) }\end{array}$ & $\begin{array}{l}\text { LI7559_21020 } \\
\text { (contig40_59850_59500) }\end{array}$ & $\begin{array}{l}\text { LI17339_15170 } \\
\text { (contig06_267014_266677) }\end{array}$ \\
\hline & global nitrogen regulator & $\operatorname{tnr} A$ & $\begin{array}{l}\text { Ll6934_15560 } \\
\text { (contig31_18775_18443) }\end{array}$ & $\begin{array}{l}\text { L17559_22170 } \\
\text { (contig47_44732_45064) }\end{array}$ & $\begin{array}{l}\text { LI17339_00475 } \\
\text { (contig01_88311_87979) }\end{array}$ \\
\hline
\end{tabular}


Table 2 Overview of gene inventory involved in nitrogen metabolism, transport and regulation of Bacillus licheniformis (Continued)

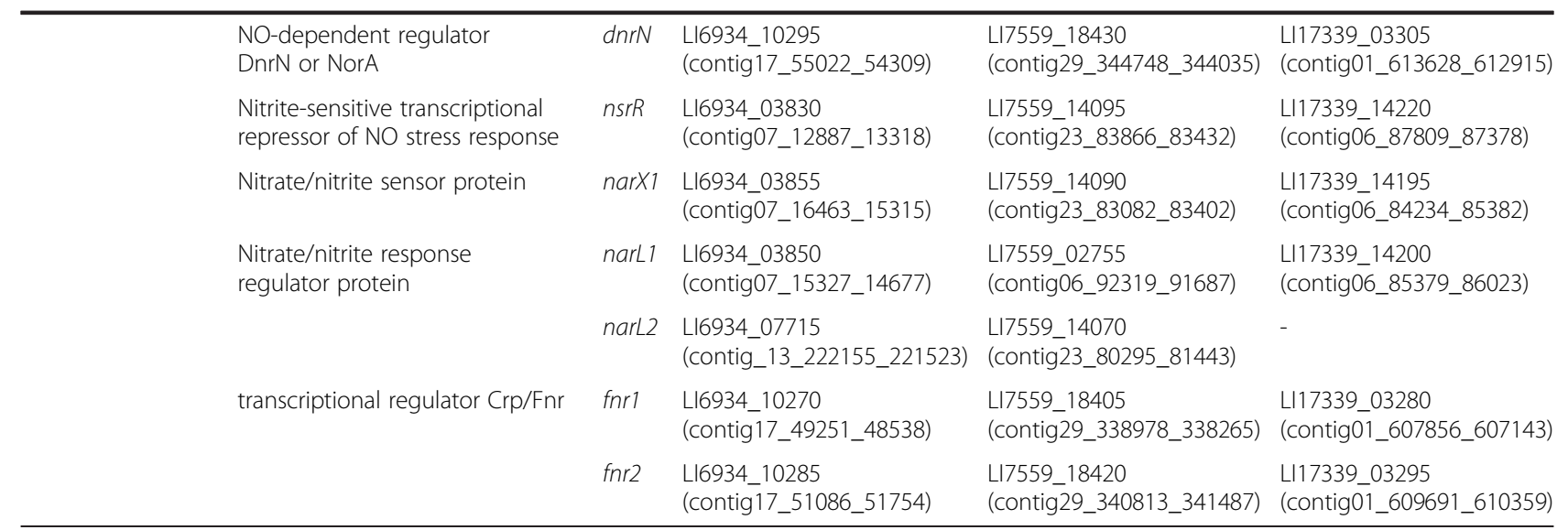

nucleotide identities (ANI) of the genomes from the strains within BALI1 $(99.70 \% \pm 0.03)$ and BALI2 $(98.92 \% \pm 0.03)$ were well-above the arbitrary 94-95\% cut-off criterion for species delineation, while between group ANI values were ambiguous $(94.24 \% \pm 0.07)$ [54, 55]. Interestingly, comparison of the NarG sequences of the three $B$. licheniformis genomes from this study, all other publically available $B$. licheniformis genomes and representatives of other Bacillus species showed two distinct clusters, each supported by high bootstrap values (Additional file 1: Figure S1). NarG1 from LMG 6934, NarG2 from LMG 7559 and NarG from LMG 17339 grouped within the BALI 1 cluster, consisting of sequences derived only from $B$. licheniformis and one Bacillus sp. NarG2 from LMG 6934 and NarG1 from LMG 7559 fell within cluster BALI2, which also included B. bataviensis and one of the two NarGs from B. azotoformans. In addition, all $B$. licheniformis genomes from BALI1 consistently harbored only one copy of the nar operon, two copies of narK and one copy of hmp, in contrast to those from BALI2 with two nar operons, three narK copies and two hmp copies (data not shown).

\section{Discussion}

\section{General metabolism}

Strains belonging to the species $B$. licheniformis have often been considered as denitrifiers $[5,18]$, based on their ability to produce gaseous end-products specifically $\mathrm{N}_{2} \mathrm{O}$ from nitrate. However, our analyses demonstrated that $B$. licheniformis, like B. subtilis $[27,28]$, is capable of nitrate respiration and fermentative dissimilatory nitrite reduction to ammonium rather than denitrification. All currently available $B$. licheniformis genomes lack a nirK- or nirS-type nitrite reductase and growth experiments with three strains confirmed that nitrogen gasses were not produced in stoichiometric amounts. B. licheniformis first reduced nitrate to nitrite (Fig. 1, $\mu 1$ ), using the cytoplasmic NarGHI, to support growth accumulating high levels of nitrite before subsequently switching to fermentation after nitrate got depleted. During fermentation (Fig. 1, $\mu 2$ ), ammonium was produced from nitrite, probably using the NADP-dependent nitrite reductase NirBD (also called NasDE) that can serve for both assimilation and dissimilation. For B. subtilis it is still undetermined if nitrite reduction is coupled to energy production through proton motive force [28]. However, since nitrite reduction and production of $\mathrm{N}_{2} \mathrm{O}$ continued after growth had ceased, as described before for other non-denitrifying $\mathrm{N}_{2} \mathrm{O}$ producers [30, 56, 57], these $\mathrm{N}$ conversion seem unrelated to energy conservation. Nevertheless, during fermentative growth, DNRA can serve as an electron-sink allowing re-oxidation of $\mathrm{NADH}$ with the generation of one extra ATP by

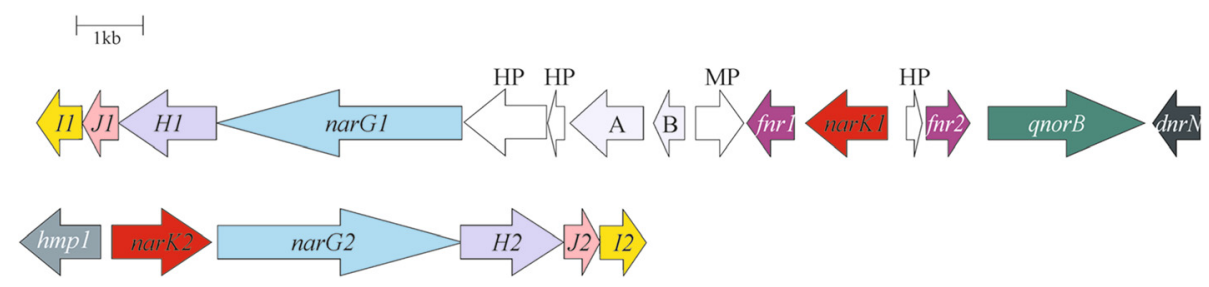

Fig. 3 Physical map of B. licheniformis LMG 6934 and LMG 7559 nar gene clusters and their genome environment. Arrows show the direction of transcription. Open reading frames are drawn to scale. Homologous genes are shown in identical colors. Note that LMG 17339 only contains nar1 gene cluster with identical genome environment except for an extra HP immediately upstream of narG1. HP, hypothetical protein; MP, membrane protein; A, gene for the radical SAM domain heme biosynthesis protein; B, gene for a probable transcription regulator arfM 
substrate level phosphorylation for each acetate produced $[58,59]$.

\section{Hypothesis for $\mathrm{NO}$ and $\mathrm{N}_{2} \mathrm{O}$ formation}

To our knowledge, $\mathrm{NO}$ or $\mathrm{N}_{2} \mathrm{O}$ production and associated cellular mechanisms have never been described for the model organism B. subtilis. Therefore, we built on the knowledge from other model organisms to deduce plausible hypotheses to explain our observations (Fig. 4). Nitrite conversion to $\mathrm{NO}$ in E. coli was shown to occur only after nitrate was depleted, in presence of molybdate - the cofactor of NarGHI -, continued in nirB-mutants [60] but was absent in narG-mutants [61], suggesting that the NarGHI had a double function and converted nitrite to NO. Also in Salmonella enterica serovar Typhimurium, NarGHI was unequivocally responsible for NO generation from nitrite, which was completely eliminated in a narGHI mutant [62]. Later mutagenesis experiments in E. coli could not confirm the involvement of the cytoplasmic nitrate reductase in $\mathrm{NO}$ evolution, probably because the experiments were conducted in the absence of nitrate and thus lacked nitrite formed from NarGHI activity during growth [63]. Rather NirB and NrfA, besides their primary role converting nitrite to ammonium, appeared to be involved in NO production [63], with their relative importance dependent on the nitrite concentration $[64,65]$. But, in contrast to $B$. vireti capable of DNRA in combination with NosZmediated $\mathrm{N}_{2} \mathrm{O}$ reduction [30] but similar to B. subtilis, $B$. licheniformis lacks a $n r f A$ gene. Furthermore, the activity of NO synthase (NOS), which produces NO from arginine as a defense mechanism against oxidative stress under aerobic conditions in B. subtilis [66], is unlikely under our hypoxic test conditions, making the involvement of NarGHI or NirB in the generation of NO from nitrite most plausible (Fig. 4).
Next, NO homeostasis is crucial to limit the toxicity of $\mathrm{NO}$, which is a reactive nitrogen species capable of damaging bacterial proteins, lipids and DNA, and binding to metal centers. $\mathrm{NO}$ can freely diffuse through the membrane and can be converted to $\mathrm{N}_{2} \mathrm{O}$ in the periplasmic-like space by the quinol-dependent $\mathrm{NO}$ reductase qNor (Fig. 4). This reductase is known to be present both in denitrifiers and non-denitrifiers [67-70], including pathogenic bacteria where it is part of their defense mechanism against nitrosative stress. In addition, B. licheniformis genomes also encode the flavohemoglobin Hmp. Hmp, found both in cytoplasm and periplasm [71], is known to convert $\mathrm{NO}$ to nitrate aerobically and to $\mathrm{N}_{2} \mathrm{O}$ anaerobically [72, 73]. However, as the latter conversion is at greatly reduced activity [74], it is unsure whether this enzyme is relevant for NO detoxification in B. licheniformis with qNorB; indeed hmp appeared not to upregulated in anaerobic conditions at high levels of nitrite in $B$. vireti that contained a copper-dependent NO reductase type 1 [30]. The periplasmic NrfA [75, 76] and the cytoplasmic flavorubredoxin NorV and its associated oxidoreductase NorW $[49,50]$ that can both anaerobically reduce $\mathrm{NO}$ to ammonium and/or $\mathrm{N}_{2} \mathrm{O}$, are not found in B. licheniformis. Notably, the gene inventory for anaerobic nitrate and nitrite metabolism in $B$. licheniformis and $B$. subtilis only seems to differ in the presence of a qnor $B$ gene in the former organism, making it likely that $B$. subtilis is capable of NO production. This was hinted at by micromolar range $\mathrm{N}_{2} \mathrm{O}$ production by B. subtilis 1A01 [77] for which the genome is unfortunately not available. Mutagenic and transcriptomic studies are necessary to confirm our hypothetic pathways for $\mathrm{NO}$ and $\mathrm{N}_{2} \mathrm{O}$ production in B. licheniformis.

\section{$\mathrm{N}$ end-products: environmental significance and microdiversity}

Non-denitrifying nitrate reducers, mostly belonging to Enterobacteriaceae or Bacillaceae, have been reported to

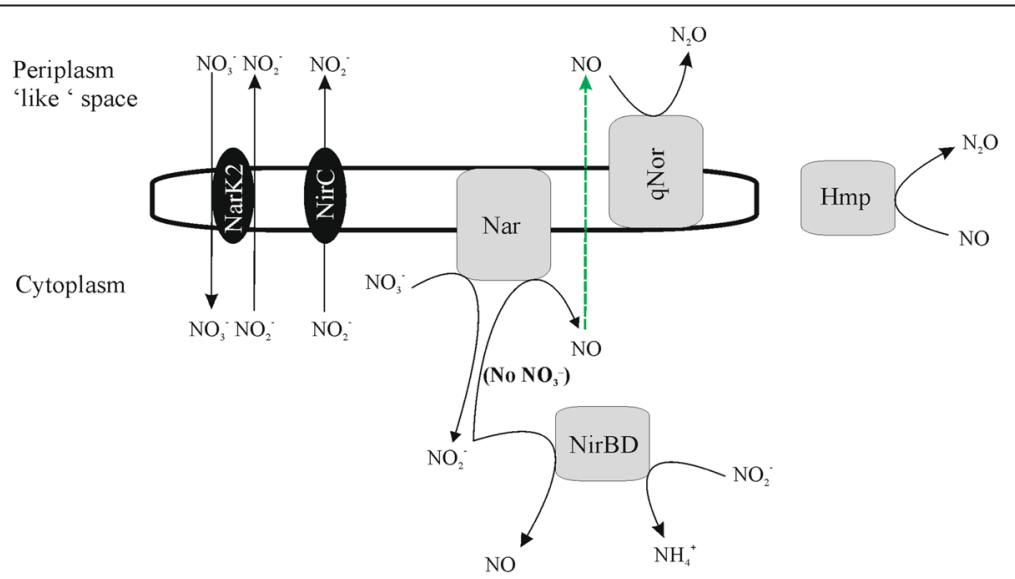

Fig. 4 Proposed hypothetical pathways for anaerobic nitrogen reduction in B. licheniformis. Schematic representation of enzymes are given in grey, transporters in black. Diffusion of gaseous NO through cytoplasmic membrane is indicated by the dashed arrow. Soluble Hmp can be located in the cytoplasm and periplasm 
reduce typically about 5 to $10 \%$ of nitrate to $\mathrm{N}_{2} \mathrm{O}$, with sometimes high quantities up to $35 \%$, which evolved mostly after growth has ceased [30, 56, 57, 65, 77]. For B. licheniformis, measured $\mathrm{N}_{2} \mathrm{O}$ production from nitrate was within these ranges but was nevertheless quite substantial, with up to one-third of all nitrate converted to $\mathrm{N}_{2} \mathrm{O}$ (Fig. 2). How environmentally relevant these $\mathrm{N}_{2} \mathrm{O}$ emissions from non-denitrifiers are remains difficult to establish without ways to differentiate them from denitrification; in isotope pairing experiments, nondenitrifiers will also produce ${ }^{30} \mathrm{~N}-\mathrm{N}_{2} \mathrm{O}$. In addition, even with mechanistic understanding, deducing specific target genes for molecular surveys will be nearly impossible, as different mechanisms have already been described for a single microorganisms like E. coli [78], S. thyphimurium [62] and B. vireti [30] and the genes involved have dual functions, e.g. NarG, NirB and NrfA.

Despite high $\mathrm{N}_{2} \mathrm{O}$ emission, most nitrite was indeed converted to ammonium (12.2 - $51.0 \%)$, which is in agreement with previous observations for pure cultures under nitrate limitation (valid for both growth conditions applied here as growth continued via fermentation after nitrate depletion) [30, 56, 77]. Interestingly, the ratio of end-products from nitrate varied quite substantially between all three B. licheniformis strains. However, as differences were also apparent between LMG 6934 and LMG 7559, this phenotypic heterogeneity could not be linked the specific gene duplications in BALI2 genomes. An alternative explanation might be distinct regulatory motifs in the promotor regions of the genes involved, although the same regulatory genes were encoded in the three genomes with identical relative genome locations (Table 2). It is long been accepted that closely related bacteria do not necessarily share the capacity to denitrify, and even when they do, can have different denitrifying phenotypes. However, our data suggest that phenotypic heterogeneity or niche differentiation between closely related strains, which has recently been reported for $\mathrm{N}_{2} \mathrm{O}$ production in Bacillus [79], Thauera [80] and Methylomonas [81], might not always be linked to genetic variation.

\section{Conclusions}

Using physiological and genomic data we have demonstrated that the common soil bacterium $B$. licheniformis does not denitrify but is capable of fermentative dissimilatory nitrate/nitrite reduction to ammonium with concomitant production of $\mathrm{N}_{2} \mathrm{O}$. Based on the genomic inventory, alternative routes for $\mathrm{N}_{2} \mathrm{O}$ production, similar to those in Enterobacteriaceae and thus far unreported in bacilli, were proposed. Significant strain-dependent differences were found between three closely related strains that could not be linked to genetic features. Considering its ubiquitous nature and non-fastidious growth in the lab, B. licheniformis is a suitable candidate for further exploration of the uncertainty of the mechanism of $\mathrm{N}_{2} \mathrm{O}$ production in DNRA bacteria and its relevance in situ.

\section{Availability of supporting data}

All the supporting data are included as additional files.

\section{Additional file}

\begin{abstract}
Additional file 1: Figure S1. Phylogenetic tree of full-length NarG. Sequences were taken from genomes included in the manuscript as well as all from publically available B. licheniformis genomes (dd June 2014) and genomes from other Bacillus species, protein ID or locus tag is given between brackets. The evolutionary history was inferred using the Neighbor-Joining method. The optimal tree with the sum of branch length $=1,68972248$ is shown. The percentage of replicate trees in which the associated taxa clustered together in the bootstrap test (500 replicates) are shown next to the branches. The evolutionary distances were computed using the Poisson correction method and are in the units of the number of amino acid substitutions per site. All positions containing gaps and missing data were eliminated. There were a total of 1094 positions in the final dataset. Evolutionary analyses were conducted in MEGA6. Figure S2. Phylogenetic tree of full-length Nark. Sequences were taken from several Bacillus species, as well as reference genomes, locus tag is given between brackets. The evolutionary history was inferred using the Neighbor-Joining method. The optimal tree with the sum of branch length $=6,03046656$ is shown. The percentage of replicate trees in which the associated taxa clustered together in the bootstrap test (500 replicates) are shown next to the branches. The tree is drawn to scale, with branch lengths in the same units as those of the evolutionary distances used to infer the phylogenetic tree. The evolutionary distances were computed using the Poisson correction method and are in the units of the number of amino acid substitutions per site. All positions containing gaps and missing data were eliminated. There were a total of 358 positions in the final dataset. Evolutionary analyses were conducted in MEGA6. Figure S3. Whole genome clustering based on a similarity matrix using the peptidome content, in which amino acid sequences of a genome are converted to tryptic peptides, i.e. the tryptic peptidome. All publically available B. licheniformis genomes (dd June 2014) were included and are designated by their strain number: 9945A (accession number NC_021362), ATCC 14580 (accession number NC_006270), DSM 13 (=ATCC 14580; accession number NC_006322), 5-2-D (accession number NZ_AJLW01000000), F1-1 (accession number NZ_AZSL01000000), 3F-3 (accession number NZ_JFYM01000000), F2-1 (accession number NZ_AZSM01000000), WX-02 (accession number NZ_JH636050), 10-1-A (accession number NZ_AJLV01000001), CGMCC 3963 (accession number NZ AMWQ01000000), CG-B52 (accession number NZ AVEZ01000000). Analyses were performed using the Peptidome tool (http://unipept.ugent.be/). (DOCX $29 \mathrm{~kb}$ )
\end{abstract}

\section{Abbreviations}

DNRA: Dissimilatory nitrate/nitrite reduction to ammonium; TSB: Trypticase soy broth; RAST: Rapid annotation subsystem technology; ANI: Average nucleotide identity; MM: Mineral medium; OD: Optical density.

\section{Competing interests}

The authors declare to have no competing interests.

\section{Authors' contributions}

$\mathrm{YH}$ performed the growth experiments, data analyses and wrote the paper; $\mathrm{KH}$ conceived the study, performed genome data analyses and wrote the paper; PDV helped with interpretation of data and revised the paper. All authors have read and approved the manuscript.

\section{Acknowledgements}

YS was funded by Chinese Scholarship Council (File number 201206330054) and BOF CSC co-funding from Ghent University (grant 01SC2713). KH was funded by the Fund for Scientific Research (FWO), Flanders for a position as postdoctoral research fellows (grants FWO11/PDO/0840 and FWO15/PDOH1/ 
084). Genome sequencing was also funded by FWO (grant FWO11/KAN/043). This research was also supported by Ghent University Research Council (GOA project 01G01911). The funders had no role in study design, data collection and interpretation, or the decision to submit the work for publication.

\section{Author details}

'Department of Biochemistry and Microbiology, Laboratory of Microbiology, (LM-UGent), University of Ghent, K.L. Ledeganckstraat 35, 9000 Gent, Belgium. ${ }^{2}$ BCCM/LMG Bacteria Collection, K.L. Ledeganckstraat 35, 9000 Gent, Belgium.

\section{Received: 13 October 2015 Accepted: 6 January 2016}

\section{Published online: 19 January 2016}

\section{References}

1. Zumft WG. Cell biology and molecular basis of denitrification. Microbiol Mol Biol Rev. 1997;61(4):533-616.

2. Canfield DE, Glazer AN, Falkowski PG. The evolution and future of earth's nitrogen cycle. Science. 2010;330:192-6.

3. Pichinoty F, de Barjac $H$, Mandel M, Asselineau J. Description of Bacillus azotoformans sp. nov. Int J Syst Bacteriol. 1983;33:660-2.

4. Pichinoty F, Durand M, Job C. Etude morphologique, physiologique et taxonomique de Bacillus azotoformans. Can J Microbiol. 1978;24:608-17.

5. Pichinoty F, Garcia JL, Job C, Durand M. La dénitrification chez Bacillus licheniformis. Can J Microbiol. 1978;24:45-9.

6. Pichinoty F, Mandel M, Garcia JL. The properties of novel mesophilic denitrifying Bacillus cultures found in tropical soils. J Gen Microbiol. 1979;115:419-30.

7. Denariaz G, Payne WJ, Legall J. A halophilic denitrifier, Bacillus halodenitrificans sp. nov. Int J Syst Bacteriol. 1989;39:145-51.

8. Payne WJ. Denitrification. New York: John Wiley \& Sons; 1981.

9. Braker G, Fesefeldt A, Witzel K-P. Development of PCR primer systems for amplification of nitrite reductase genes (nirk and nirS) to detect denitrifying bacteria in environmental samples. Appl Environ Microbiol. 1998;64(10):3769-75.

10. Throback IN, Enwall K, Jarvis A, Hallin S. Reassessing PCR primers targeting nirs, nirk and nos $Z$ genes for community surveys of denitrifying bacteria with DGGE. FEMS Microbiol Ecol. 2004:49:401-17.

11. Penton CR, Johnson TA, Quensen JF, Iwai S, Cole JR, Tiedje JM. Functional genes to assess nitrogen cycling and aromatic hydrocarbon degradation: primers and processing matter. Front Microbiol. 2013;4:279.

12. Wei W, Isobe K, Nishizawa T, Zhu L, Shiratori Y, Ohte N, et al. Higher diversity and abundance of denitrifying microorganisms in environments than considered previously. ISME J. 2015;9(9):1954-65.

13. Mohan SB, Schmid M, Jetten M, Cole J. Detection and widespread distribution of the nrfA gene encoding nitrite reduction to ammonia, a short circuit in the biological nitrogen cycle that competes with denitrification. FEMS Microbiol Ecol. 2004;49:433-43.

14. Welsh A, Chee-Sanford J, Connor L, Loffler F, Sanford R. Refined NrfA phylogeny improves PCR-based nrfA gene detection. Appl Environ Microbiol. 2014;80:2110-9.

15. Felske A, Akkermans ADL, De Vos WM. In Situ detection of an uncultured predominant Bacillus in Dutch Grassland soils. Appl Environ Microbiol. 1998;34(11):4588-90.

16. Maeda K, Hanajima D, Toyoda S, Yoshida N, Morioka R, Osada T. Microbiology of nitrogen cycle in animal manure compost. Microb Biotechnol. 2011;4:700-9.

17. Park SJ, Yoon JC, Shin KS, Kim EH, Yim S, Cho YJ, et al. Dominance of endospore-forming bacteria on a rotating activated Bacillus contactor biofilm for advanced wastewater treatment. J Microbiol (Seoul, Korea). 2007; 45(2):113-21.

18. Verbaendert I, Boon N, De Vos P, Heylen K. Denitrification is a common feature among members of the genus Bacillus. Syst Appl Microbiol. 2011:34:385-91.

19. Heylen K, Keltjens J. Redundancy and modularity in membrane-associated dissimilatory nitrate reduction in Bacillus. Front Microbiol. 2012:3:371.

20. Nielsen M, Schreiber L, Finster K, Schramm A. Draft genome sequence of Bacillus azotoformans MEV2011, a (Co-) denitrifying strain unable to grow with oxygen. Stand Genomic Sci. 2014;9:23.

21. Lu S, Suharti, Vries S, Moënne-Loccoz P. Two CO molecules can bind concomitantly at the diiron site of $\mathrm{NO}$ reductase from Bacillus azotoformans. J Am Chem Soc. 2004;126:15332-3.
22. Suharti, Heering HA, de Vries S. NO reductase from Bacillus azotoformans is a bifunctional enzyme accepting electrons from menaquinol and a specific endogenous membrane-bound cytochrome c551. Biochemistry. 2004:43:13487-95.

23. Suharti, Strampaard MJF, Schröder I, de Vries S. A novel copper A containing menaquinol NO reductase from Bacillus azotoformans. Biochemistry. 2001;40:2632-9.

24. Al-Attar S, de Vries S. An electrogenic nitric oxide reductase. FEBS Lett. 2015. 589(16):2050-7.

25. Suharti, de Vries S. Membrane-bound denitrification in the Gram-positive bacterium Bacillus azotoformans. Biochem Soc Trans. 2005;33(1):130-3.

26. Simon J, Klotz MG. Diversity and evolution of bioenergetic systems involved in microbial nitrogen compound transformations. Biochim Biophys Acta. 2013;1827(2):114-35.

27. Nakano MM, Hoffmann T, Zhu Y, Jahn D. Nitrogen and oxygen regulation of Bacillus subtilis nasDEF encoding NADH-dependent nitrite reductase by TnrA and ResDE. J Bacteriol. 1998;180(20):5344-50.

28. Nakano MM, Zuber P. Anaerobic growth of a "strict aerobe" (Bacillus subtilis). Annu Rev Microbiol. 1998:52:165-90.

29. Switzer Blum J, Burns Bindi A, Buzzelli J, Stolz JF, Oremland RS. Bacillus arsenicoselenatis, sp. nov., and Bacillus selenitireducens, sp. nov.: two haloalkaliphiles from Mono Lake, California that respire oxyanions of selenium and arsenic. Arch Microbiol. 1998;171(1):19-30.

30. Mania D, Heylen K, van Spanning RJ, Frostegard A. The nitrate-ammonifying and nosZ carrying bacterium Bacillus vireti is a potent source and sink for nitric and nitrous oxides under high nitrate conditions. Environ Microbiol. 2014;16:3196-210.

31. Dhakal R, Seale RB, Deeth HC, Craven H, Turner MS. Draft genome comparison of representatives of the three dominant genotype groups of dairy Bacillus licheniformis strains. Appl Environ Microbiol. 2014;80(11):3453-62.

32. Li L, Su F, Wang Y, Zhang L, Liu C, Li J, et al. Genome sequences of two thermophilic Bacillus licheniformis strains, efficient producers of platform chemical 2,3-butanediol. J Bacteriol. 2012;194(15):4133-4.

33. Rachinger M, Volland S, Meinhardt F, Daniel R, Liesegang $H$. First Insights into the Completely Annotated Genome Sequence of Bacillus licheniformis Strain 9945A. Genome Announc. 2013; 1(4):00525-13.

34. Rey MW, Ramaiya P, Nelson BA, Brody-Karpin SD, Zaretsky EJ, Tang M, et al. Complete genome sequence of the industrial bacterium Bacillus licheniformis and comparisons with closely related Bacillus species. Genome Biol. 2004;5:R77.

35. Veith B, Herzberg C, Steckel S, Feesche J, Maurer KH, Ehrenreich P, et al. The complete genome sequence of Bacillus licheniformis DSM13, an organism with great industrial potential. J Mol Microbiol Biotechnol. 2004;7:204-11.

36. Wu Q, Peng S, Yu Y, Li Y, Xu Y. Genome Sequence of Bacillus licheniformis CGMCC3963, a Stress-Resistant Strain Isolated in a Chinese Traditional SolidState Liquor-Making Process. Genome Announcements. 2013; 1(1):00060-12.

37. Pitcher DG, Saunders NA, Owen RJ. Rapid extraction of bacterial genomic DNA with guanidium thiocyanate. Lett Appl Microbiol. 1989:8:151-6.

38. Heyndrickx M, Vauterin L, Vandamme P, Kersters K, De Vos P. Applicability of combined amplified ribosomal DNA restriction analysis (ARDRA) patterns in bacterial phylogeny and taxonomy. J Microbiol Meth. 1996;26:247-59.

39. Overbeek R, Olson R, Pusch GD, Olsen GJ, Davis JJ, Disz T, et al. The SEED and the Rapid Annotation of microbial genomes using Subsystems Technology (RAST). Nucleic Acids Res. 2014;42(Database issue):D206-214.

40. Aziz RK, Bartels D, Best AA, DeJongh M, Disz T, Edwards RA et al. The RAST Server: Rapid Annotations using Subsystems Technology. BMC Genomics. 2008; 9(75):doi:10.1186/1471-2164-1189-1175.

41. Altschul SF, Madden TL, Schäffer AA, Zhang J, Zhang Z, Miller W, et al. Gapped BLAST and PSI-BLAST: a new generation of protein database search programs. Nucleic Acids Res. 1997;25:3389-402.

42. Zdobnov EM, Apweiler R. InterProScan - an integration platform for the signature-recognition methods in InterPro. Bioinformatics. 2001;17(9):847-8.

43. Goris J, Konstantinidis KT, Klappenbach JA, Coenye T, Vandamme P, Tiedje JM. DNA-DNA hybridization values and their relationship to whole-genome sequence similarities. Int J Syst Evol Microbiol. 2007;57:81-91.

44. Stanier RY, Palleroni NJ, Doudoroff M. The aerobic pseudomonads: a taxonomic study. J Gen Microbiol. 1966:43(2):159-271.

45. Baethgen WE, Alley MM. A manual colorimetric procedure for measuring ammonium nitrogen in soil and plant Kjeldahl digests. Commun Soil Sci Plant Anal. 1989;20:9-10. 
46. Griess P. Bemerkungen zu der abhandlung der H.H. Weselsky und Benedikt "Ueber einige azoverbindungen". Chem Ber. 1879;12:426-8.

47. Cataldo DA, Haroon M, Schrader LE, Youngs VL. Rapid colorimetric determination of nitrate in plant-tissue by nitration of salicylic-acid. Commun Soil Sci Plant Anal. 1975;6:71-80.

48. Navarro-Gonzalvez JA, Garcia-Benayas C, Arenas J. Semiautomated measurement of nitrate in biological fluids. Clin Chem. 1998;44(3):679-81.

49. Gomes CM, Giuffre A, Forte E, Vicente JB, Saraiva LM, Brunori M, et al. A novel type of nitric-oxide reductase. Escherichia coli flavorubredoxin. J Biol Chem. 2002;277(28):25273-6.

50. van Wonderen JH, Burlat B, Richardson DJ, Cheesman MR, Butt JN. The nitric oxide reductase activity of cytochrome $c$ nitrite reductase from Escherichia coli. J Biol Chem. 2008;283:9587-94.

51. Mesuere B, Devreese B, Debyser G, Aerts M, Vandamme P, Dawyndt P. Unipept: tryptic peptide-based biodiversity analysis of metaproteome samples. J Proteome Res. 2012:11(12):5773-80.

52. Mesuere B, Debyser $G$, Aerts M, Devreese B, Vandamme P, Dawyndt P. The Unipept metaproteomics analysis pipeline. Proteomics. 2015;15(8):1437-42

53. De Clerck E, De Vos P. Genotypic diversity among Bacillus licheniformis strains from various sources. FEMS Microbiol Lett. 2004;231(1):91-8.

54. Konstantinidis KT, Tiedje JM. Genomic insights that advance the species definition for prokaryotes. Proc Natl Acad Sci U S A. 2005;102:2567-72.

55. Konstantinidis KT, Ramette A, Tiedje JM. The bacterial species definition in the genomic era. Phil Trans R Soc B. 2006:361:1929-40.

56. Smith MS, Zimmerman K. Nitrous oxide production by nondenitrifying soil nitrate reducers. Soil Sci Soc Am J. 1981:45(5):865-71.

57. Bleakley BH, Tiedje JM. Nitrous oxide production by organisms other than nitrifiers or denitrifiers. Appl Environ Microbiol. 1982;44(6):1342-8.

58. Cole J. Nitrate reduction to ammonia by enteric bacteria: redundancy, or a strategy for survival during oxygen starvation? FEMS Microbiol Lett. 1996;136(1):1-11.

59. Polcyn W, Podeszwa J. Coordinate induction of dissimilatory ammonification and fermentative pathways in rhizobia. Antonie Van Leeuwenhoek. 2009;96(1):79-87.

60. Smith MS. Dissimilatory reduction of $\mathrm{NO}_{2}^{-}$to $\mathrm{NH}_{4}^{+}$and $\mathrm{N}_{2} \mathrm{O}$ by a soil Citrobacter sp. Appl Environ Microbiol. 1982;43:854-60.

61. Smith MS. Nitrous oxide production by Escherichia coli is correlated with nitrate reductase activity. Appl Environ Microbiol. 1983;45(5):1545-7.

62. Gilberthorpe NJ, Poole RK. Nitric oxide homeostasis in Salmonella typhimurium: roles of respiratory nitrate reductase and flavohemoglobin. J Biol Chem. 2008;283(17):11146-54

63. Corker H, Poole RK. Nitric oxide formation by Escherichia coli. Dependence on nitrite reductase, the NO-sensing regulator Fnr, and flavohemoglobin Hmp. J Biol Chem. 2003;278(34):31584-92.

64. Wang $H$, Robert $O$, Hall J, Gunsalus $P$. The nrfA and nirB nitrite reductase operons in Escherichia coli are expressed differently in response to nitrate than to nitrite. J Bacteriol. 2000;182(20):5813-22.

65. Rowley G, Hensen D, Felgate H, Arkenberg A, Appia-Ayme C, Prior K, et al. Resolving the contributions of the membrane-bound and periplasmic nitrate reductase systems to nitric oxide and nitrous oxide production in Salmonella enterica serovar Typhimurium. Biochem J. 2012;441(2):755-62.

66. Adak S, Aulak KS, Stuehr DJ. Direct evidence for nitric oxide production by a nitric-oxide synthase-like protein from Bacillus subtilis. J Biol Chem. 2002; 277(18):16167-71.

67. Büsch A, Friedrich B, Cramm R. Characterization of the norB gene, encoding nitric oxide reductase, in the nondenitrifying cyanobacterium Synechocystis sp. Strain PCC6803. Appl Environ Microbiol. 2002;68(2):668-72.

68. Cramm R, Siddiqui RA, Friedrich B. Two isofunctional nitric oxide reductases in Alcaligenes eutrophus H16. J Bacteriol. 1997;197(21):6769-77.

69. Philippot L. Denitrifying genes in bacterial and Archaeal genomes. Biochim Biophys Acta. 2002;1577:355-76.

70. Heylen K, Vanparys B, Gevers D, Wittebolle L, Boon N, De Vos P. Nitric oxide reductase (norB) gene sequence analysis reveals discrepancies with nitrite reductase (nir) gene phylogeny in cultivated denitrifiers. Environ Microbiol. 2007;9(4):1072-7.

71. Vasudevan SG, Tang P, Dixon NE, Poole RK. Distribution of the flavohaemoglobin, HMP, between periplasm and cytoplasm in Escherichia coli. FEMS Microbiol Lett. 1995;125(2-3):219-24
72. Gardner PR, Gardner AM, Martin LA, Salzman AL. Nitric oxide dioxygenase: an enzymic function for flavohemoglobin. Proc Natl Acad Sci U S A. 1998;95(18):10378-83.

73. Kim SO, Orii Y, Lloyd D, Hughes MN, Poole RK. Anoxic function for the Escherichia coli flavohaemoglobin (Hmp): reversible binding of nitric oxide and reduction to nitrous oxide. FEBS Lett. 1999:445(2-3):389-94.

74. Mills CE, Sedelnikova S, Soballe B, Hughes MN, Poole RK. Escherichia coli flavohaemoglobin ( $\mathrm{Hmp}$ ) with equistoichiometric FAD and haem contents has a low affinity for dioxygen in the absence or presence of nitric oxide. Biochem J. 2001;353(Pt 2):207-13.

75. Poock SR, Leach ER, Moir JWB, COle JA, Richardson DJ. Respiratory detoxification of nitric oxide by the cytochrome $c$ nitrite reductase of Escherichia coli. J Biol Chem. 2002;277:23664-9.

76. Costa C, Macedo A, Moura I, Moura JJG, Le Gall J, Berlier Y, et al. Regulation of the hexaheme nitrite/nitric oxide reductase of Desulfovibrio desulfuricans, Wolinella succinogenes and Escherichia coli. FEBS Lett. 1990;276:67-70.

77. Streminíska MA, Felgate H, Rowley G, Richardson DJ, Baggs EM. Nitrous oxide production in soil isolates of nitrate-ammonifying bacteria. Environ Microbiol Rep. 2012;4(1):66-71.

78. Vine CE, Cole JA. Nitrosative stress in Escherichia coli: reduction of nitric oxide. Biochem Soc Trans. 2011;39:313-5.

79. Jones CM, Welsh A, Throback IN, Dorsch P, Bakken LR, Hallin S. Phenotypic and genotypic heterogeneity among closely related soil-borne $\mathrm{N}$ - and $\mathrm{N} \mathrm{O}$-producing Bacillus isolates harboring the nosZ gene. FEMS Microbiol Ecol. 2011;76(3):541-552.

80. Liu B, Mao Y, Bergaust L, Bakken LR, Frostegard A. Strains in the genus Thauera exhibit remarkably different denitrification regulatory phenotypes. Environmental microbiology. 2013;15(10):2816-2828.

81. Hoefman S, van der Ha D, Boon N, Vandamme P, De Vos P, Heylen K. Niche differentiation in nitrogen metabolism among methanotrophs within an operational taxonomic unit. BMC microbiology. 2014;14(1):83.

\section{Submit your next manuscript to BioMed Central and we will help you at every step:}

- We accept pre-submission inquiries

- Our selector tool helps you to find the most relevant journal

- We provide round the clock customer support

- Convenient online submission

- Thorough peer review

- Inclusion in PubMed and all major indexing services

- Maximum visibility for your research

Submit your manuscript at www.biomedcentral.com/submit 